\title{
Thinking theoretically about male violence against women in rural places: A review of the extant sociological literature and suggestions for future theorizing*
}

\author{
Walter S. DeKeseredy \\ Anna Deane Carlson Endowed Chair of Social Sciences, \\ Director of the Research Center on Violence, and \\ Professor of Sociology \\ West Virginia University \\ UNITED STATES OF AMERICA \\ Callie M. Rennison \\ Professor \\ School of Public Affairs \\ University of Colorado- Denver \\ UNITED STATES OF AMERICA \\ Contact author - Walter S. DeKeseredy; walter.dekeseredy@mail.wvu.edu \\ *This is a revised version of a paper presented at the November 2019 annual meetings of the \\ American Society of Criminology, San Francisco, CA. The authors would like to thank Joseph F. \\ Donnermeyer for his assistance.
}

\begin{abstract}
Sociological research on male-to-female violence against women in rural places has mushroomed over the past 20 years. Nonetheless, theoretical developments are not keeping pace with the burgeoning contemporary empirical literature. This article reviews the current state of sociological theoretical work in the field and suggests new ways of thinking theoretically about woman abuse in rural places.
\end{abstract}

Keywords: theory, woman abuse, rural, sociology 


\section{Introduction}

Repeatedly stated in the mushrooming rural criminological literature is the fact that criminology is urban biased. However, an international wave of rural scholarship is now aggressively chipping away at the urban criminological Bastille. Consider the wealth of interdisciplinary knowledge included in Donnermeyer's (2016a) Routledge International Handbook of Rural Criminology. Also, the Rural Criminology Division of the American Society of Criminology was born in 2018 and the University of New England launched the world's first rural crime research center on September 9, 2019. Furthermore, under the editorial leadership of Donnermeyer, The International Journal of Rural Criminology features "cutting-edge" articles and he is the Editor of the new Routledge Studies in Rural Criminology book series.

It is beyond the scope of this article to chronicle all of the exciting contemporary developments in rural criminology, but it must be emphasized that, in this current epoch, rural criminology does not dwell on "throwing stones" at criminology's urban bias. Throwing stones, according to Indigenous criminologist Juan Tauri (personal communication), means simply criticizing traditional or orthodox variants of criminology. Donnermeyer (2016b) notes that it is always "easy to fall prey to an exaggerated mindset of blame and accusation about urban parochial colleagues whose indifference or even antagonism to rural crime studies speaks to unspoken forms of academic discrimination" (p. 8). Yet, rural criminology has advanced far beyond its first era (1933-1973) and is now less celebratory and much more self-critical. ${ }^{1}$ This article exemplifies this point and its main objective is twofold: (1) to provide a review of the current state of sociological theoretical work on male-to-female violence in rural places and (2) to put forward new theoretical directions.

\section{The current state of sociological theoretical knowledge}

The simultaneous advancement of theory and research devoted to crime and social control in rural contexts remains uneven, with research far outpacing theory (Donnermeyer \& DeKeseredy, 2014). Moreover, until recently, place-based explanations, such as social disorganization theory, were the dominant theoretical frameworks (Harris \& Harkness, 2016). One would not know this, however, if he or she limited his or her reading of rural criminology to sociological work on male-to-female violence. Conceptual and theoretical work in this area draws primarily from feminist offerings (DeKeseredy, 2019a). As well, applications of placebased theories found in the rural violence against women sociological literature deviate significantly from mainstream ecological perspectives like collective efficacy theory. Collective efficacy is generally defined as "mutual trust among neighbors combined with a willingness to act on behalf of the common good, specifically to supervise children and maintain public order" (Sampson et al., 1998, p. 1).

Feminist rural criminologists are among the first scholars ${ }^{2}$ to show that this view of collective efficacy is one-dimensional, focused only on aspects of localized forms of social structure which reduce only certain kinds of crime (Donnermeyer \& DeKeseredy, 2014). It is true that many rural people, including criminal justice officials, share strong ties through kinship systems and friendship networks. Additionally, many rural citizens are less tolerant of numerous crimes and are more likely to support punitive approaches to violations of legal norms than are 
metropolitan residents (DeKeseredy et al., 2007). Nonetheless, feminist researchers DeKeseredy and Schwartz (2009) found that collective efficacy in rural areas takes different shapes and forms and is not necessarily restricted to deterring or preventing woman abuse. Furthermore, what outsiders may perceive to be as social disorganization is actually a form of social organization. Social disorganization is "the inability of a community structure to realize the common values of its residents and maintain effective controls" (Sampson \& Groves, 1989, p. 777).

DeKeseredy and Schwartz (2009) found no evidence of social disorganization in three rural southeast Ohio communities but rather discovered forms of collective efficacy or social organization that allow individuals to learn about and behave in ways that sustain and reinforce the abuse of women. For example, $67 \%$ of their 43 female respondents reported on a variety of ways in which their ex-partners' male peers encouraged and legitimated separation/divorce sexual assault and other violent behaviors. Similarly, prior to DeKeseredy and Schwartz's project, Websdale (1998) discovered a powerful "ol' boys' network" that functioned to dominate and oppress rural Kentucky women.

Patriarchal forms of social organization are not restricted to the United States (U.S.) because, as Renzetti (2013) correctly points out, "In Western societies, and in most societies throughout the world, the gender structure is patriarchal" (p. 8). For instance, Jakobsen (2016) found that violence against women in rural Tanzania is a type of "community law enforcement" that "enforces community norms with the permission of the state to maintain a specific social order" (p. 415). Likewise, in another part of the Global South - Australia, Saunders (2015) found that sexual harassment in rural workplaces is a "cultural norm" and "a debilitating condition (as with a disease) that has grown and spread to the point of excessive prevalence within particular communities" (p. 2). Saunders also discovered that male bonding or "mateship" is a powerful determinant of sexual harassment, as it is of numerous other forms of woman abuse (DeKeseredy \& Schwartz, 2013).

The above four studies are theoretically refreshing because they show that collective efficacy "can go both ways" (Donnermeyer \& DeKeseredy, 2014). It can now be concluded that male peer support, neighbor non-intervention, and rural norms of patriarchy and privacy, all of which are expressions of collective efficacy (not social disorganization), are significant predictors of variants of woman abuse that exist on what Kelly $(1987,1988)$ denotes as the continuum of sexual violence, ranging from nonphysical acts such as sexual harassment to physical ones like rape or striking a woman with a fist. Though Kelly's conceptual tool is a valuable construct that highlights the commonalities and cumulative effects of seemingly distinct abusive behaviors (McGlynn et al., 2017), it was only applied in urban contexts until Saunders (2015) used it in her research on workplace sexual harassment in rural Australia.

The idea of the continuum is often employed to portray moving from the least serious to the most serious, but to feminist scholars like Kelly (1988), sexual harassment, sexual violence, physical violence, and other types of violence against women are all serious and have a "basic common character" because they are all types of "abuse, intimidation, coercion, intrusion, threat, and force" used to control and dominate women (p. 76). Note, too, that non-physical forms of abuse, especially sexual harassment, are much more common in women's lives than are physical and sexual violence (DeKeseredy et al., 2019; Kelly, 2012), with studies showing that catcalls, 
harassment, and unwanted sexual attention can have major long-term psychological effects starting even before girls become teenagers (Castillo, 2018).

To the best of our knowledge, Saunders is the only rural scholar thus far to draw from Kelly's work. Others are likely to soon do so because her research supports Kelly's (2012) claim that the continuum of sexual violence continues to "stand the test of time" (p. xvii). So do the concepts of male peer support and patriarchy, which are integral components of the extant theoretical literature on male violence against women in rural places. The former is widely defined as attachments to male peers and the resources that these men provide that encourage and legitimate woman abuse (DeKeseredy, 1988). On the other hand, the definition of patriarchy is much debated within feminism, but it is still widely used because, as Hunnicutt (2009) puts it, "it keeps the gaze directed toward social contexts rather than toward individual men who are motivated to dominate" (p. 554). If, for convenience, a simple definition of patriarchy had to be chosen, it might be good to follow Renzetti (2013): "a gender structure in which men dominate women, and what is considered masculine is more highly valued than what is considered feminine" (p.8). While there are passionate disagreements about how to conceptualize patriarchy, all rural feminist criminologists concur that any theory of male-to-female violence "must use the structure of rural patriarchy, in all its intricate manifestations, as an essential frame of reference" (Websdale, 1998, p. 194). Two chief examples are DeKeseredy et al.'s (2004) feminist/male peer support model of separation/divorce sexual assault and DeKeseredy et al.'s (2007) rural masculinity crisis/male peer support model of separation/divorce sexual assault. It should be noted in passing that DeKeseredy et al.'s (2004) model is the first rural-focused middle-range theory (Merton, 1949) of crime to be informed by feminism (Donnermeyer, 2018).

Presented in Figures 1 and 2, space limitations preclude an in-depth discussion of these offerings, but perhaps, for the purposes of this article, they are best described by Donnermeyer (2018) who notes that they emphasize:

the consequences of strong patriarchal norms in many rural communities as a type of normative structure that socialize and reinforce men's rationalizations for verbally and physically abusing their partners. Explicitly feminist in... orientation, [they] continuously linked social structural change within the broader economic, social and cultural dimensions of rural America. Their attempt was to remove both the "gender blind" and theory-less properties of past rural crime studies and model a future rural criminology that was more critical and more conceptually sophisticated. (pp. 390-391) 
Figure 1: A Feminist/Male Peer Support Model of Separation/Divorce Sexual Assault

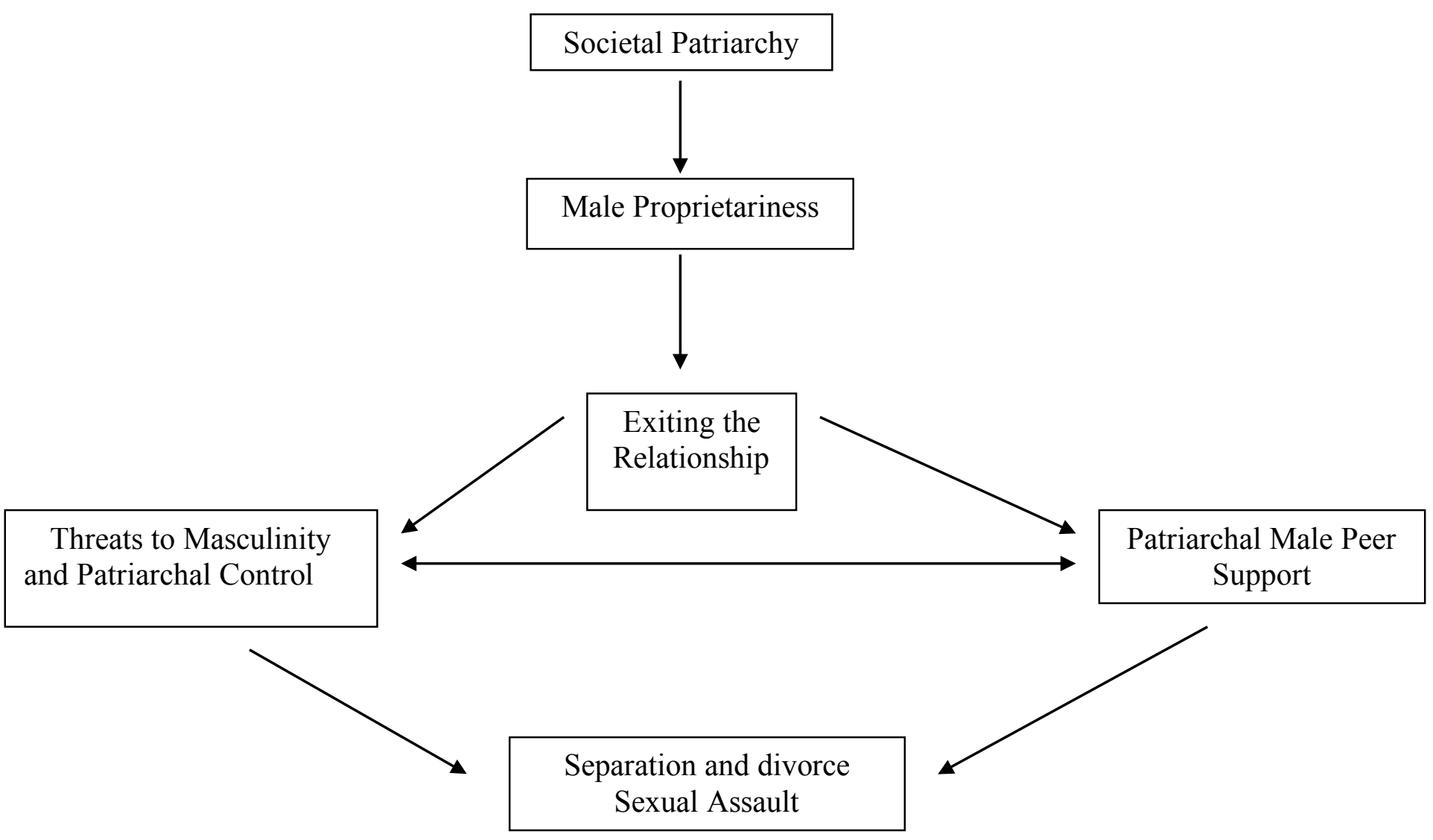

Figure 2: A Rural Masculinity Crisis/Male Peer Support Model of Separation/Divorce Sexual Assault

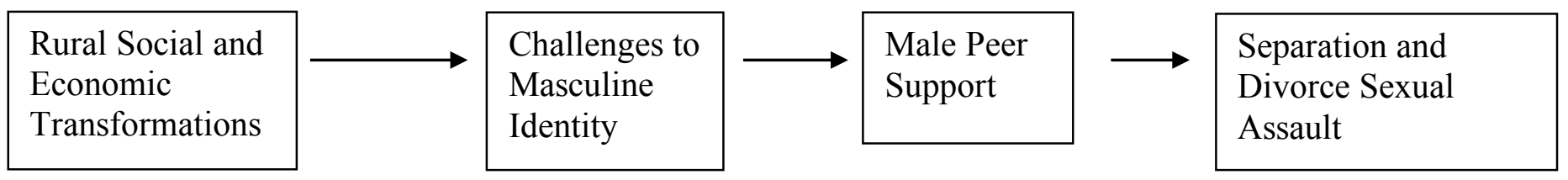

DeKeseredy and his colleagues' above contributions also helped move critical criminology from the periphery to the core of contemporary theoretical work on crime and social control in rural contexts (Donnermeyer, 2018). Of course, there are, and should be, other ways of thinking critically about crime in rural and remote places. One example is Donnermeyer and DeKeseredy's $(2008,2014)$ effort to develop a new left realist perspective. Informed by, and compatible with, feminism (DeKeseredy \& Schwartz, 2018; Renzetti, 2013), left realism was born in the mid-1980s in the U.S. and the United Kingdom. Left realists point to the criminogenic consequences of broader social forces such as patriarchy and capitalism. They also 
borrow from mainstream theoretical work done by strain theorists Merton (1938) and Cohen (1955).

Left realists are concerned about crimes of the powerful (e.g., corporate and state crime), but the bulk of their theoretical work focuses on street crime, "hard" police tactics (e.g., stopping and searching publicly drunk people), and woman abuse in intimate relationships (DeKeseredy \& Schwartz, 2018). The main reason for this is that prior to the 1980s, most critical criminologists focused almost solely on crimes of the powerful, as well as on the influence of class and race/ethnic relations on definitions of crime and the administration of justice. Hence, the plight of victims of street crime and violence behind closed doors was given short shrift. This allowed right-wing politicians in several countries to claim opposition to interpersonal violence as their own, giving them the room to generate ideological support for harsh "law and order" policies like lengthy prison terms for drug crimes (DeKeseredy \& Schwartz, 2018).

One British left realist ${ }^{3}$ theory centers on the negative outcomes of criminalizing incivilities, such as public drunkenness and panhandling in urban communities (Kinsey et al., 1986). Referred to as the square of crime or what Lea (2010) calls the social relations of crime control, it focuses on four interacting elements: victim, offender, state agencies (e.g., the police), and the public. Depicted in Figure 3, Young (1992) describes the social relationships between each point on the square:

It is the relationship between the police and the public which determines the efficacy of policing, the relationship between the victim and the offender which determines the impact of crime, the relationship between the state and the offender which is a major factor in recidivism. (p. 27)

Figure 3: The Square of Crime

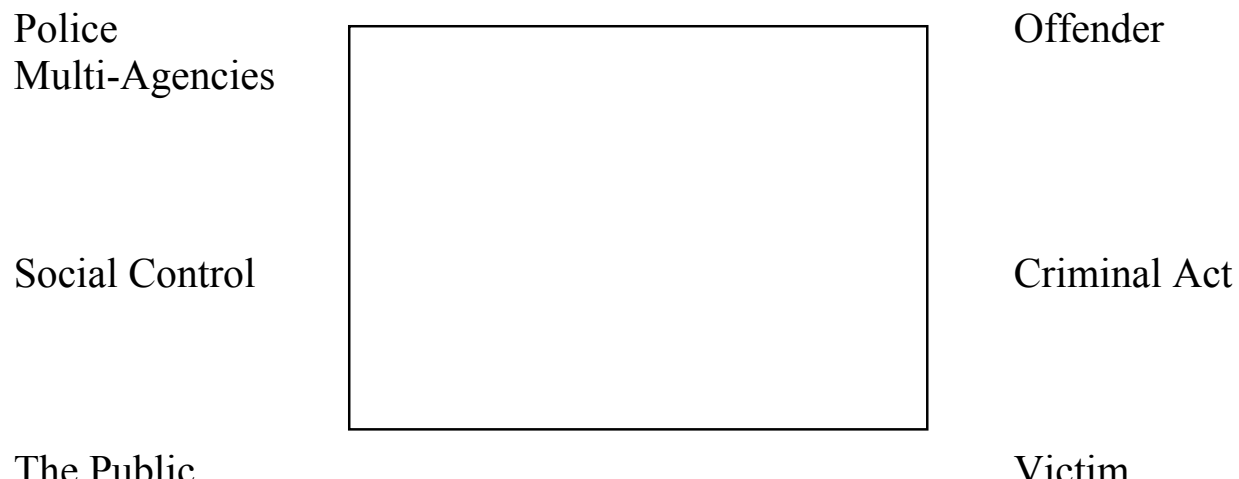

Though dated and designed to focus chiefly on inner-city crime, Donnermeyer and DeKeseredy's $(2008,2014)$ attempt to start the development of a rural critical criminology shows that unlike the early and new Chicago Schools of criminology, the square of crime is not intrinsically urban biased. Instead, it is a useful way to understand the fundamental dimensions of crime at multiple levels and in different places. The square of crime illustrates that crime rates 
in many urban and rural communities are outcomes of four interrelated causes: (1) the causes of offending (e.g., unemployment and peer group membership); (2) factors that make victims vulnerable (e.g., lifestyles/routine activities); (3) the social conditions that influence public levels of control and tolerance; and (4) the social forces that propel agents of social control (e.g., police) (Young, 1992, p. 30).

Developing left realist theories of various types of rural-located crime does not necessarily require ditching concepts included in explanations of crime in urban contexts (DeKeseredy \& Donnermeyer, 2013). For example, DeKeseredy et al.'s (2007) rural masculinity/male peer support model of rural separation/divorce sexual assault (see Figure 2) is heavily influenced by a British left realist theory that includes the concepts of relative deprivation and subculture. This perspective argues that people lacking legitimate means of solving the problem of relative deprivation may come into contact with other frustrated, disenfranchised people and form subcultures, which, in turn, encourage and legitimate criminal behaviors (Lea \& Young, 1984).

Rural critical criminology is also starting to engage with intersectionality (Carrington et al., 2014), which is another type of feminism, one with roots in Black feminist theory and critical race theory (Collins \& Bilge, 2016; Potter, 2015). Intersectionality entails examining "the manner in which racism, patriarchy, class oppression, and other discriminatory systems create background inequalities that structure the relative positions of women, races, ethnicities, classes, and the like" (Crenshaw, 2000, p. 8). Intersectionality is front and center in almost all of the contemporary North American feminist criminological literature on the violent experiences of inner-city African-American girls and women, but it has yet to gain momentum in theoretical work on male-to-female violence in rural and remote areas.

The innovations of cultural criminology are also being injected into rural critical criminological theories, one of which is DeKeseredy et al.'s (2014) gendered perspective on the horrification and pornification of rural culture. There are various definitions of cultural criminology, but this one offered by Ferrell (2003) is possibly the most intelligible to those unfamiliar with this critical criminological school of thought. Cultural criminology:

critically investigates the ways in which the dynamics of media and popular culture, the lives and activities of criminals, and the operations of social control and criminal justice come together in everyday life. Cultural criminologists emphasize the role of image, style, and symbolic meaning among criminals and their subcultures, in the mass media's representation of crime and criminal justice, and in public conflicts over crime and crime control. (p. 71)

DeKeseredy et al. (2014) define horrification as the persistent depiction of any group of people within a particular society as either the perpetrators and/or victims of extreme forms of violence by various visual, print, and other mass media genres, and its distribution. Likewise, they conceptualize pornification as the persistent depiction of any group of people within a particular society as either the perpetrators and/or the victims of extreme forms of sexual behavior and exploitation, including violent and racist portrayals of heterosexual sex in various mass media, and its distribution and use within society. 
There is much brutal male-to-female violence in contemporary horror movies and porn that feature rural people (DeKeseredy \& Corsianos, 2016; McCollum, 2017). In fact, such violence is now the norm and is increasing in severity. For example, Atkinson and Rodgers (2016) and DeKeseredy and Hall-Sanchez (2018) sensitize us to the rapid growth of gorno or gore porn movies, such as The Woman. These films combine sadism, torture, and porn, and they generate huge revenues for their producers and distributors. That there are sequels to gorno movies like Hostel and Saw is a powerful commentary on how violent pornography has seeped into mainstream popular culture.

Why does the horrification and pornification of rural women continue to flourish? Informed by DeKeseredy (2013), DeKeseredy et al. (2014) provide a radical feminist answer to this question. Radical feminists assert that the most important set of social relations in any society if found in patriarchy and that, throughout the world, females are the most oppressed social group, while, regardless of their race/ethnicity and social class, men always have more power and privilege (Renzetti, 2013).

DeKeseredy et al. (2014) assert that highly degrading and grossly distorted media representations of male-to-female violence serve the interests of men who abuse female intimates. These images support the myth that sexual assaults, femicides, and beatings are committed only by pathological "sex fiends" and that women enjoy "rough sex" depicted in cyber porn (Beckett \& Sasson, 2000). Many scholars probably disagree with their interpretation and maintain that what they are really describing is the consequence of consuming rural horror and porn. In addition, while the interests of abusive and patriarchal men may be served, the violent media discussed here are highly profitable and therefore some would argue that this is a key determinant of their production. Certainly, porn generates huge profits and so do rural slasher films (DeKeseredy, 2019b). DeKeseredy et al. are fully aware of this and recognize that both arguments -feminist and the economics - further a critical examination of the horrification and pornification of the rural.

\section{New directions}

DeKeseredy (2019a) argued that theoretical developments in the field of rural woman abuse are keeping pace with the burgeoning empirical literature. This is not the case now. The same can be said about theories of other types of crime that occur in rural communities. For example, an entire book and an entire anthology on theories of rural crime and social control are yet to be published. Accordingly, there is much work to do, some of which are suggested here. Most, if not all, rural criminologists would agree with Donnermeyer's (2019) observation: "The explanation... of violence... in the context of rural America needs a far firmer theoretical base than is currently displayed in the literature" (p. 116). A firmer theoretical base is, in fact, much needed in rural violence scholarship produced around the around.

Noted earlier, there has been a strong emphasis on using elements of male peer support and feminist theories to explain separation/divorce sexual assault. Can parts of these perspectives also effectively explain other forms of woman abuse in rural places like beatings in marital/cohabiting relationships and acquaintance rapes? Turning first to male peer support, over 30 years of research shows that it is both ubiquitous and correlated with a broad range of brutal 
male behaviors in different types of heterosexual relationships (DeKeseredy, 2019c; DeKeseredy \& Schwartz, 2013). Male peer support theorists are firmly convinced that what Bowker (1983) claimed 36 years ago about all-male, patriarchal subcultures of violence is correct:

This is not a subculture that is confined to a single class, religion, occupational grouping or race. It is spread throughout all parts of society. Men are socialized by other subculture members to accept common definitions of the situation, norms, values, and beliefs about male domination and the necessity of keeping [women] in line. These violencesupporting social relations may occur at any time and in any place. (pp. 135-136)

Also, keep in mind what Dragiewicz (2011) concluded in her review of the empirical work on male peer support and violence against women:

Studies have documented the influence of patriarchal peer support for men's violence at the mesosystem ${ }^{3}$ level in a variety of contexts, including studies of battered wives, dating violence, batterer narratives, campus sexual assault, separation assault, and woman abuse in representative samples. (p. 13)

Dragiewicz is correct, as demonstrated by an ever-growing international body of scholarship showing that male peer support influences men from many walks of life to abuse women in numerous ways (Brubaker, 2019; DeKeseredy, 2019c). Still, empirical work done so far does not reveal that male peer support strongly contributes to rural male assaults on women other than those that occur during and after separation/divorce. This research gap needs to be filled before it can be concluded that Dragiewicz's observation is applicable to patriarchal, violent rural men in general. Moreover, not all rural places are alike (Donnermeyer, 2018). Is it then possible that male peer support models like those in Figures 1 and 2 are only applicable to the plight of women living in rural Southeast Ohio? This is an important question because these offerings emerged from qualitative research done there. Much more research in other rural contexts, including those in the Global South, is required before claiming that male peer support is a strong determinant of all types of woman abuse in all types of rural places.

The difference between the Global North and the Global South is "the divide between the metropolitan states of Western Europe and North America, on the one hand, and the countries of Latin American, Africa, Asia and Oceania, on the other" (Carrington et al., 2015, p. 2). There is some research on male peer support in the Global South, including that done in Australia by Carrington et al. (2010) and Saunders (2015), as well as the work of Jewkes et al. (2006) in South Africa. Even so, nowhere to be found in the sociological literature on male peer support in the Global South are full-fledged theoretical models like those in Figures 1 and 2. This will probably change in the near future because new advances are being made by those involved in the project of southern criminology, many of whom are feminists (e.g., Carrington, 2015). Drawing heavily on the work of Connell (2007), southern criminologists challenge criminology's Northern colonialism and to quote Donnermeyer (2017), they offer a perspective that is "more capable of considering, both theoretically and empirically, crime and justice in the Global South" (p. 121). 
The way forward also involves testing models such as Figures 1 and 2 using quantitative data. To date, empirical support for them comes from semi-structured interviews with small groups of rural women, and thus the findings cannot be generalized to larger populations. This gap can be filled because five validated male peer support measures are readily available and they have been successfully used in large-scale surveys conducted in urban places (e.g., DeKeseredy \& Schwartz, 1998). Measures of men's adherence to the ideology of familial patriarchy (male domination and control of women in domestic/intimate settings) are also on hand and have produced findings published in widely read and cited journals (e.g., DeKeseredy $\&$ Kelly, 1993; Smith, 1990). The question of how to generate sampling frames and administer probability-based criminological surveys in rural areas remains unanswered, but this is a topic for another article.

Like male peer support models, feminist theories of rural woman abuse need to be "expanded and enhanced" (Brubaker, 2019). Again, intersectionality is one direction to take. So is the development of perspectives that integrate mainstream general criminal theories of crime with feminism. Integrated theories, as illustrated in Figures 1 and 2, exist, but they are primarily feminist in orientation. This is definitely not a limitation, but a few theories of woman abuse in other contexts show that middle-range offerings attacked for ignoring gender may still have useful theoretical constructs when combined with feminist insights.

One salient example is Godenzi et al.'s (2001) gendered social bond/male peer support theory of university woman abuse, which rethinks Hirschi's (1969) conception of conformity and deviance. Hirschi's social bond theory is an inherently conservative explanation of crime and ignores any notion of gendered power (Belknap, 2006). ${ }^{4}$ Yet, Godenzi et al. turned much of Hirschi's argument upside down by arguing that bonds to conventional institutions can increase woman abuse on college campuses because gender inequality is an unacknowledged norm.

Guided by Hobbes $(1651,1963)$, Hirschi presupposed that people are naturally deviant or criminal and that there is no need to explain something that is natural. Rather, that which is unnatural - conformity - is what must be theorized. He contends that criminal or delinquent behaviors result when the bond to conventional society is weak or broken. People who have a strong social bond to conventional peers and social institutions (e.g., school, nuclear family, religion, etc.) are more likely to obey the law because these bonds all promote mutual respect and pro-social behavior. Godenzi et al.'s offering is also a theory of conformity, but they contend in colleges plagued by alarmingly high rates of sexual assault and the presence of all-male, proabuse subcultures, it is men who do not engage in woman abuse who are the deviants and whose bond to the dominant patriarchal order is weak or broken.

Hirschi's view of a social control theory is that it tries to explain why a man who believes in a norm is willing to violate it. If, as Godenzi et al. suggest, this man learns an alternative set of beliefs that legitimates the behavior, and nullify societal beliefs against this behavior, then, as Hirschi states, "there is within the context of the theory, nothing to explain" (p. 23). Godenzi et al. contend that woman abuse on campus is socially learned in societies, small groups, or institutions that view woman abuse as a normal and legitimate way of interacting with women. The purpose of Godenzi et al.'s theory, however, was not to show that Hirschi's formulation was correct, but that the addition of a gendered sensitivity and the insights of male peer support 
theory could make Hirschi's offering useful in explaining the existence of woman abuse on college campuses. Similarly, based on data collected by DeKeseredy and Schwartz (2009) and Jakobson (2016) showing that collective efficacy enables male-to-female violence in rural communities, it is now time for critics of Sampson (2012) and his like-minded colleagues (e.g., Sampson et al., 1998) to recognize that these gender-blind ecological theorists have important insights when integrated with feminist thought. They have a "golden opportunity" to create a gendered collective efficacy theory of woman abuse in rural areas.

Shadowing DeKeseredy et al.'s (2019) college campus study, rural woman abuse researchers should conduct quantitative studies that apply either a continuum of sexual abuse or polyvictimization model to the problem of male-to-female violence in rural places.

Polyvictimization refers to "the experiences of multiple victimizations of different kinds, such as sexual victimization, witnessing family violence, and exposure to community violence, not just multiple episodes of the same kind of victimization" (Mitchell et al., 2018; p. 762, emphasis in original). Studying polyvictimization is important not only for empirical and theoretical reasons related to the application of Kelly's $(1987,1988)$ continuum, but also because focusing on this problem helps rural advocates, counselors, criminal justice officials, and other professionals offer more effective prevention and intervention practices (DeKeseredy \& Rennison, 2019; Finkelhor, 2018).

There is theoretical literature that supports the logical argument that webs of abuse promulgate more abuse, but the empirical nature of this work in rural communities is primarily qualitative, such as Saunders' (2015) 84 in-depth interviews with Australian workplace sexual harassment survivors. ${ }^{5}$ Quantitative studies like DeKeseredy et al.'s (2019) are valuable to develop rich contextual data. More of this research should be done in rural communities to document the manner in which different types of male-to-female violence "seep into one another" and function as mechanisms of social control (Phoenix, 2012; Ptacek, 2016, p. 128).

\section{Conclusion}

Theorizing male violence against women in rural and other places is an important sociological act (Ellis, 1987). Even so, this is not evident from reading the extant social scientific literature produced in the last 16 years. Most violence against women authors are now based in psychology, psychiatry, nursing, and medicine and the bulk of the research they publish in journals is atheoretical (DeKeseredy, in press; DeKeseredy \& Rennison, 2019; Jordan, 2009). Therefore, taking the steps suggested above, though not an exhaustive blueprint, is not only about crafting new theories of rural woman abuse, but also about generating fresh sociological theories of male-to-female violence in any context.

The marginalization of sociological thought in the field of woman abuse is part of a broader trend (DeKeseredy \& Rennison, 2019). In fact, sociological insights are being pushed out of criminological studies in general. Eminent criminologist and former President of the American Society of Criminology Francis T. Cullen (2009) noticed this movement 10 years ago and stated: "I am... persuaded that sociological criminology has exhausted itself as a guide for the future study on the origins of crime. It is a paradigm for the previous century, not the current one" (p. $\mathrm{xvi})$. 
Our goal is not to help push other social scientific theoretical and empirical perspectives out to make sociological offerings the dominant ways of understanding woman abuse regardless of where it occurs. Rather, we embrace the interdisciplinary nature of violence against women studies and we intend to grant sociology equal status, especially sociological theorizing. The publication of Brubaker's (2019) book Theorizing Gender Violence is a sign that this may be starting to happen.

Another part of the process of moving forward theoretically is remembering Warr's (2002) observation: "Criminal conduct is predominantly social behavior. Most offenders are embedded in a network of friends who break the law, and the single strongest predictor of criminal behavior known to criminologists is the number of delinquent friends an individual has" (p. 3). Warr's empirically informed claim reminds us about the value of thinking sociologically and reinforces calls for prioritizing the concept of male peer support in sociological theories of rural woman abuse. Additionally, it is necessary to put the concept of patriarchy front and center because the vast majority of men who abuse women do not suffer from personality disorders (DeKeseredy, in press; Gondolf, 2012). In reality, acts of male-to-female violence are primarily caused by broader patriarchal forces in conjunction with other social determinants like male peer support (Pease, 2019).

\section{Endnotes}

${ }^{1}$ See Donnermeyer (2016b) for a history of rural criminology.

${ }^{2}$ See also Barclay et al.'s (2004) research on the “dark side" of Tonnies' (2002/1887) concept of Gemeinschaft.

${ }^{3}$ The mesosystem is a level of influence included in ecological models of violence (Carlson, 1984; Heise, 1998; World Health Organization, 2002). Other levels included are individual, interpersonal, community, and culture. Dragiewicz (2011) asserts, "the mesosystem is the more important part of the ecological model because it describes the cumulative interaction of all of the other levels upon a person" (p. 20).

${ }^{4}$ Hirschi (1969) explicitly ignored female experiences, excluding their self-report survey data from his statistical analysis, although he does report that this exclusion is "difficult to justify." In his book Causes of Delinquency, Hirschi states in a footnote that "in the analysis which follows, the 'non-Negro' becomes 'white,' and the girls disappear" (p. 35). Following this, virtually all tests of social bond theory have used all-male samples.

${ }^{5}$ Saunders also conducted 23 interviews with rural employers and she did a statistical and analytical analysis of 68 adjudicated workplace sexual harassment cases heard throughout Australia between 2005 and 2010. 


\section{References}

Atkinson, R., \& Rodgers, T. (2016). Pleasure zones and murder boxes: Online pornography and violent video games as cultural zones of exception. The British Journal of Criminology, 56, 1291-1307. https://doi.org/10.1093/bjc/azv113

Barclay, E., Donnermeyer, J. F., \& Jobes, P. C. (2004). The dark side of Gemeinschaft. Crime Prevention and Community Safety, 6, 7-22. https://doi.org/10.1057/palgrave.cpcs.8140191

Beckett, K., \& Sasson, T. (2000). The politics of injustice: Crime and punishment in America. Sage. https://doi.org/10.4135/9781452229614

Belknap, J. (2006). The invisible woman: Gender, crime and justice, $3^{\text {rd }}$ ed. Wadsworth.

Bowker, L. H. (1983). Beating wife-beating. Lexington Books.

Brubaker, S. J. (2019). Theorizing gender violence. Cognella.

Carlson, B. E. (1984). Causes and maintenance of domestic violence: An ecological analysis. Social Services Review, 58, 569-587. https://doi.org/10.1086/644239

Carrington, K. (2015). Feminism and global justice. Routledge. https://doi.org/10.4324/9781315748368

Carrington, K., Donnermeyer, J. F., \& DeKeseredy, W. S. (2014). Intersectionality, rural criminology, and re-imaging the boundaries of critical criminology. Critical Criminology, 22, 463-477. https://doi.org/10.1007/s10612-014-9257-0

Carrington, K., Hogg, R., \& Sozzo, M. (2015). Southern criminology. British Journal of Criminology, 56, 1-20. https://doi.org/10.1093/bjc/azv083

Carrington, K., McIntosh, A., \& Scott, J. (2010). Globalization, frontier masculinities and violence: Booze, blokes and brawls. British Journal of Criminology, 50, 393-413. https://doi.org/10.1093/bjc/azq003

Cohen, A. K. (1955). Delinquent boys: The culture of the gang. Free Press.

Collins, P. H., \& Bilge, S. (2016). Intersectionality. Polity.

Connell, R. (2007). Southern theory: The global dynamics of knowledge in social science. Allen \& Unwin. https://doi.org/10.22459/AHR.44.2008.04

Crenshaw, K. (2000). The intersectionality of race and gender discrimination. Background Paper, Expert Group Meeting on Gender and Race Discrimination, Zagreb, Croatia, November 21-24, 2000. 
Cullen, F. T. (2009). Preface. In A. Walsh \& K. M. Beaver (Eds.), Biosocial criminology: New directions in theory and research (pp. $\mathrm{xv}$-xvii). Routledge.

DeKeseredy, W. S. (1988). Woman abuse in dating relationships: The relevance of social support theory. Journal of Family Violence, 3, 1-13. https://doi.org/10.1007/BF00994662

DeKeseredy, W. S. (2013). The myth that "criminals" are fundamentally different from noncriminals. In R. M. Bohm \& J. T. Walker (Eds.), Demystifying crime and criminal justice (pp. 13-24). Oxford University Press.

DeKeseredy, W. S. (2019a). Intimate violence against rural women: The current state of sociological knowledge. International Journal of Rural Criminology, 4, 312-331. https://doi.org/10.18061/1811/87904

DeKeseredy, W. S. (2019b). Adult pornography and violence against women. In W. S. DeKeseredy, C. M. Rennison, \& A. K. Hall-Sanchez (Eds.), The Routledge international handbook of violence studies (pp. 224-234). Routledge. https://doi.org/10.4324/9781315270265-21

DeKeseredy, W. S. (2019c). Scholar contribution: Some reflections on male peer support theory. In S. J. Brubaker's Theorizing gender violence (pp. 45-49). Cognella.

DeKeseredy, W. S. (in press). Bringing feminist sociological analyses of patriarchy back to the forefront of the study of woman abuse. Violence Against Women.

DeKeseredy, W. S., \& Corsianos, M. (2016). Violence against women in pornography. https://doi.org/10.4324/9781315652559

DeKeseredy, W. S., \& Currie, E. (Eds.). (2019). Progressive justice in an age of repression: Strategies for challenging the rise of the right. Routledge. https://doi.org/10.4324/9781351242059

DeKeseredy, W. S., \& Donnermeyer, J. F. (2013). Thinking critically about rural crime: Toward the development of a new left realist perspective. In S. Winlow \& R. Atkinson (Eds.), New directions in crime and deviancy (pp. 206-222). Routledge.

DeKeseredy, W. S., Donnermeyer, J. F., Schwartz, M. D., Tunnell, K. D., \& Hall, M. (2007). Thinking critically about rural gender relations: Toward a rural masculinity crisis/male peer support model of separation/divorce sexual assault. Critical Criminology, 15, 295311. https://doi.org/10.1007/s10612-007-9038-0

DeKeseredy, W. S., \& Hall-Sanchez, A. (2018). Thinking critically about contemporary adult pornography and woman abuse. In W. S. DeKeseredy \& M. Dragiewicz (Eds.), Routledge handbook of critical criminology ( $2^{\text {nd }}$ ed., pp. 280-294). Routledge. https://doi.org/10.4324/9781315622040-26 
DeKeseredy, W. S., \& Kelly, K. (1993). Woman abuse in university and college dating relationships: The contribution of the ideology of familial patriarchy. Journal of Human Justice, 4, 25-52. https://doi.org/10.1007/BF02619525

DeKeseredy, W. S., Muzzatti, S. L., \& Donnermeyer, J. F. (2014). Mad men in bib overalls: Media's horrification and pornification of rural culture. Critical Criminology, 22, 179197. https://doi.org/10.1007/s10612-013-9190-7

DeKeseredy, W. S., \& Rennison, C. M. (2019). Key issues in the rape and sexual assault of adult women. In W. S. DeKeseredy, C. M. Rennison, \& A. K. Hall-Sanchez (Eds.), The Routledge international handbook of violence studies (pp. 403-418). Routledge. https://doi.org/10.4324/9781315270265-38

DeKeseredy, W. S., Rogness, M., \& Schwartz, M. D. (2004). Separation/divorce sexual assault: The current state of social scientific knowledge. Aggression and Violent Behavior, 9, 675-691. https://doi.org/10.1016/j.avb.2003.08.004

DeKeseredy, W. S., \& Schwartz, M. D. (1998). Woman abuse on campus: Results from the Canadian national survey. Sage.

DeKeseredy, W. S., \& Schwartz, M. D. (2009). Dangerous exits: Escaping abusive relationships in rural America. Rutgers University Press.

DeKeseredy, W. S., \& Schwartz, M. D. (2013). Male peer support and violence against women: The history and verification of a theory. Northeastern University Press.

DeKeseredy, W. S., \& Schwartz, M. D. (2018). Left realism: A new look. In W. S. DeKeseredy \& M. Dragiewicz (Eds.), Routledge handbook of critical criminology ( $2^{\text {nd }}$ ed., pp. 30-42). Routledge. https://doi.org/10.4324/9781315622040-4

DeKeseredy, W. S., Schwartz, M. D., Nolan, J., Mastron, N., \& Hall-Sanchez, A. (2019). Polyvictimization and the continuum of sexual abuse at a college campus: Does negative peer support increase the likelihood of multiple victimizations? The British Journal of Criminology, 59, 276-295. https://doi.org/10.1093/bjc/azy036

Donnermeyer, J. F. (Ed.). (2016a). Donnermeyer, J. F. (Ed.). (2016). The Routledge international handbook of rural criminology. Routledge. https://doi.org/10.4324/9781315755885

Donnermeyer, J. F. (2016b). Introduction to the international handbook of rural criminology In J. F. Donnermeyer (Ed.), The Routledge international handbook of rural criminology (pp. 1-10). Routledge. https://doi.org/10.4324/9781315755885-1

Donnermeyer, J. F. (2017). The place of rural in a southern cri-minology. International Journal for Crime, Justice and Social Democracy, 6, 118-132.

https://doi.org/10.5204/ijcjsd.v6i1.384 
Donnermeyer, J. F. (2018). The future of a critical rural criminology. In W. S. DeKeseredy \& M. Dragiewicz (Eds.), Routledge handbook of critical criminology ( $2^{\text {nd }}$ ed., pp. 387-397). Routledge. https://doi.org/10.4324/9781315622040-35

Donnermeyer, J. F. (2019). What's place got to do with it? Explaining violence in rural context. In W. S. DeKeseredy, C. M. Rennison, \& A. K. Hall-Sanchez (Eds.), The Routledge international handbook of violence studies (pp. 95-120). Routledge.

Donnermeyer, J. F., \& DeKeseredy, W. S. (2008). Toward a rural critical criminology. Southern Rural Sociology, 23, 4-28. https://egrove.olemiss.edu/jrss/vol23/iss2/2

Donnermeyer, J. F., \& DeKeseredy, W. S. (2014). Rural criminology. London, UK: Routledge. https://doi.org/10.4324/9780203094518

Dragiewicz, M. (2011). Equality with a vengeance: Men's rights groups, battered women, and antifeminist backlash. Northeastern University Press.

Ellis, D. (1987). The wrong stuff: An introduction to the sociological study of deviance. Collier Macmillan.

Ferrell, J. (2003). Cultural criminology. In M. D. Schwartz \& S. E. Hatty (Eds.), Controversies in critical criminology (pp. 71-84). Cincinnati, OH: Anderson Publishing.

Finkelhor, D. (2018). What is polyvictimization and why is it important? http://polyvictimization.org

Godenzi, A., Schwartz, M. D., \& DeKeseredy, W. S. (2001). Toward a gendered social bond/male peer support theory of university woman abuse. Critical Criminology, 10, 116. https://doi.org/10.1023/A:1013105118592

Gondolf, E. W. (2012). The future of batterer programs: Reassessing evidence-based practice. Northeastern University Press.

Harris, B., \& Harkness, A. (2016). Introduction: Locating regional, rural and remote crime in theoretical and contemporary context. In A. Harkness, B. Harris, \& D. Baker (Eds.), Locating crime in context and place: Perspectives on regional, rural and remote Australia (pp. 1-12). The Federation Press.

Heise, L. L. (1998). Violence against women: An integrated ecological framework. Violence Against Women, 4, 262-290. https://doi.org/10.1177/1077801298004003002

Hirschi, T. (1969). Causes of delinquency. Berkeley, CA: University of California Press.

Hobbes, T. (1651, 1963). Leviathan. Meridian Books. 
Hunnicutt, G. (2009). Varieties of patriarchy and violence against women: Resurrecting "patriarchy" as a theoretical tool. Violence Against Women, 15, 553-573. https://doi.org/10.1177/1077801208331246

Jakobsen, H. (2016). Community law enforcement in rural Tanzania. In J. F. Donnermeyer (Ed.), The Routledge international handbook of rural criminology (pp. 409-417). Routledge. https://doi.org/10.4324/9781315755885-45

Jewkes, R., Dunkle, K., Koss, M. P., Levin, J. B., Nduna, M., Jama, N., \& Sikweyiya, Y. (2006). Rape perpetration by young rural South African men. Prevalence, patterns, and risk factors. Social Science and Medicine, 63, 2949-2961. https://doi.org/10.1016/j.socscimed.2006.07.027

Jordan, C. E. (2009). Advancing the study of violence against women: Evolving research agendas into science. Violence Against Women, 15, 393-419. https://doi.org/10.1177/1077801208330692

Kelly, L. (1987). The continuum of sexual violence. In J. Hanmer \& M. Maynard (Eds.), Women, violence and social control (pp. 46-60). Humanities Press International. https://doi.org/10.1007/978-1-349-18592-4_4

Kelly, L. (1988). Surviving sexual violence. University of Minnesota Press.

Kelly, L. (2012). Standing the test of time? Reflections on the concept of the continuum of sexual violence. In J. M. Brown \& S. L. Walklate (Eds.), Handbook on sexual violence (pp. xvii-Xxvi). Routledge.

Kinsey, R., Lea, J., \& Young, J. (1986). Losing the fight against crime. Blackwell.

Lea, J. (2010). Left realism, community and state building. Crime, Law and Social Change, 54, 141-158. https://doi.org/10.1007/s10611-010-9250-9

Lea, J., \& Young, J. (1984). What is to be done about law and order? Penguin.

McCollum, V. (2017). Post-9/11 heartland horror: Rural horror films in an era of urban terrorism. Routledge. https://doi.org/10.4324/9781315601601

McGlynn, C., Rackely, E., \& Houghton, R. (2017). Beyond "revenge porn": The continuum of image-based sexual abuse. Feminist Legal Studies, 25, 25-46.

https://doi.org/10.1007/s10691-017-9343-2

Merton, R. K. (1938). Social structure and anomie. American Sociological Review, 3, 672-682. https://doi.org/10.2307/2084686

Merton, R. K. (1949). Social theory and social structure. Free Press of Glencoe. 
Mitchell, K. J., Segura, A., Jones, L. M., \& Turner, H. A. (2018). Poly-victimization and peer harassment involvement in a technological world. Journal of Interpersonal Violence, 33(5), 762-788. https://doi.org/10.1177/0886260517744846

Pease, B. (2019). Facing patriarchy: Overcoming a violent gender order. Zed Books.

Phoenix, J. (2012). Violence and prostitution: Beyond the notion of a continuum of sexual violence. In J. M. Brown \& S. L. Walklate (Eds.), Handbook on sexual violence (pp. 218236). Routledge.

Potter, H. (2015). Intersectionality and criminology: Disrupting and revolutionizing studies of crime. Routledge. https://doi.org/10.4324/9780203094495

Ptacek, J. (2016). Rape and the continuum of sexual abuse in intimate relationships: Interviews with U.S. women from different social classes. In K. Yllo \& M. G. Torres (Eds.), Marital rape: Consent, marriage, and social change in global context (pp. 123-128). Oxford University Press. https://doi.org/10.1093/acprof:oso/9780190238360.003.0009

Renzetti, C. M. (2013). Feminist criminology. Routledge. https://doi.org/10.4324/9780203930311

Sampson, R. J. (2012). Great American city: Chicago and the enduring neighborhood effect. University of Chicago Press. https://doi.org/10.7208/chicago/9780226733883.001.0001

Sampson, R. J., \& Groves, W. B. (1989). Community structure and crime: Testing social disorganization theory. American Journal of Sociology, 94, 774-802. https://doi.org/10.1086/229068

Sampson, R. J., Raudenbush, S. W., \& Earls, F. (1998). Neighborhood collective efficacy: Does it help reduce violence? U.S. Department of Justice.

Saunders, S. (2015). Whispers from the bush: The workplace sexual harassment of Australian rural women. Federation Press.

Smith, M. D. (1990). Patriarchal ideology and wife beating: A test of a feminist hypothesis. Violence and Victims, 5, 257-273. https://doi.org/10.1891/0886-6708.5.4.257

Tonnies, F. (2002/1887). Community and society. Dover Publications.

Warr, M. (2002). Companions in crime: The social aspects of criminal conduct. Cambridge University Press. https://doi.org/10.1017/CBO9780511803956

Websdale, N. (1998). Rural woman battering and the criminal justice system. Sage.

World Health Organization. (2002). World report on violence and health: Summary. Geneva, Switzerland: Author. 
Thinking theoretically about male violence against women in rural places - DeKeseredy and Rennison

Young, J. (1992). Ten points of realism. In J. Young \& R. Matthews (Eds.), Rethinking criminology: The realist debate (pp. 24-68 